\title{
Asymmetric Titanium-Catalyzed Cyclopropanation of Nitriles with Grignard Reagents
}

\author{
Julien Caillé \\ Paul Setzer \\ Fabien Boeda \\ Morwenna S. M. Pearson-Long \\ Philippe Bertus*(D)
}

Le Mans Université (Université du Maine), CNRS UMR 6283, Institut des Molécules et Matériaux du Mans (IMMM),

72085 Le Mans Cedex 09, France

philippe.bertus@univ-lemans.fr
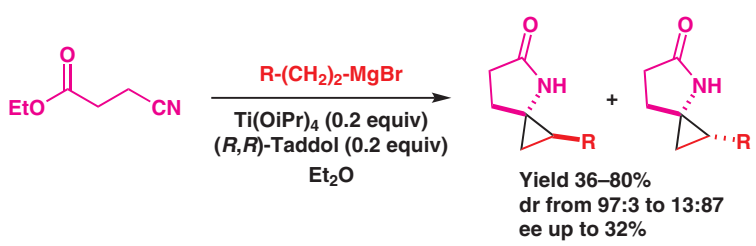

\author{
Received: 12.12 .2017 \\ Accepted: 20.01.2018 \\ Published online: 20.02 .2018 \\ DOI: 10.1055/s-0036-1591933; Art ID: so-2017-d0060-op \\ License terms: CC $0 \$$
}

\begin{abstract}
The titanium-catalyzed asymmetric cyclopropanation of cyanoesters with Grignard reagents was investigated for the first time. Particularly, the study of the efficiency of Taddol-based titanium complexes has shown that the prior preparation of Taddol titanium complexes was not required and a large panel of ligands was evaluated by using this approach. The spirocyclopropanelactams were obtained with good diastereoselectivity and with moderate enantioselectivities from the main diastereoisomer (up to $32 \%$ ).
\end{abstract}

Key words cyclopropanes, enantioselectivity, Grignard reagents, nitriles, spiro compounds, titanium

The aminocyclopropane moiety is present in a large number of biologically active compounds, ${ }^{1}$ including important active manufactured drugs present in the World Health Organization's list of Essential Medicines, ${ }^{2}$ such as ciprofloxacin (broad spectrum antibiotic), nevirapine and abacavir (anti-HIV). More specifically, chiral enantioenriched cyclopropylamines represent useful scaffolds for the preparation of drugs such as Ticagrelor ${ }^{3}$ (platelet aggregation inhibitor), Ciluprevir ${ }^{4}$ and Vaniprevir ${ }^{5}$ (hepatitis C). In addition, this motif represents an important synthetic intermediate, as pointed out in recent publications. ${ }^{6}$ In this context, the most used access to enantioenriched cyclopropylamines remains the stereoselective transition-metalcatalyzed diazoester addition to olefins, followed by a Curtius degradation. ${ }^{7}$ Several other asymmetric routes have also been explored to directly introduce the nitrogen atom during the [2+1] cycloaddition step, by using nitrogen-substituted olefins ${ }^{8}$ or $\alpha$-nitrodiazoesters. ${ }^{9}$ Zinc $\alpha$-aminocarbenoids ${ }^{10}$ or Sm-catalyzed amine addition to cyclopropenes ${ }^{11}$ were also used with success. However, the above methods suffer from several drawbacks such as catalyst availability and/or a multistep synthesis to provide the cyclopropylamine targets. Since the discovery by Kulinkovich of the Ti-catalyzed conversion of esters into cyclopropanols using Grignard reagents, ${ }^{12,13}$ two direct methods to access cyclopropylamines rapidly emerged, from $N, N$-disubstituted amides ${ }^{14}$ and from nitriles. ${ }^{15}$ In this context, the development of efficient asymmetric syntheses of cyclopropane derivatives by titanium-catalyzed cyclopropanation of acid derivatives would be an interesting alternative to syntheses described previously.

The asymmetric cyclopropanation of carboxylic acid derivatives remains in its infancy, despite the pioneering asymmetric example of the Kulinkovich reaction, described as early as $1994 .{ }^{16}$ In this reaction, cyclopropanol 1 was obtained in 65-72\% yield with an enantiomeric excess of 70$78 \%$ by using the Taddol derived spirotitanate $\mathbf{2}$ (Scheme 1 , Eq. 1). ${ }^{17} \mathrm{~A}$ few unsuccessful attempts at asymmetric cyclopropanation have been described thereafter. ${ }^{18}$ Recently, Kulinkovich reported significant results by using catalytic amounts of the Taddol complex 3 (ee up to $65 \%$, Eq. 2 ). ${ }^{19} \mathrm{Im}$ portantly, the use of hexafluoroisopropyl esters afforded the cyclopropanols in good yields and with higher enantioselectivities (up to 84\%) by using stoichiometric amounts of 3 (Eq. 3) ${ }^{19 b}$ Concerning $\mathrm{N}, \mathrm{N}$-disubstituted amides, the best results were obtained by using a stoichiometric amount of the Taddol-derived spirotitanate $4 .^{20}$ Despite a low diastereoselectivity, each aminocyclopropane was obtained with good enantioselectivity (77 and 84\% ee, Eq. 4).

With nitriles, the formation of primary cyclopropylamines occurs generally with stoichiometric amounts of titanium complexes. ${ }^{13 \mathrm{~d}} \mathrm{~A}$ notable exception is the chemoselective cyclopropanation of cyanoesters (and cyanocarbonates), leading to spirocyclic compounds (Scheme 2, top left)..$^{21}$ 
(1)
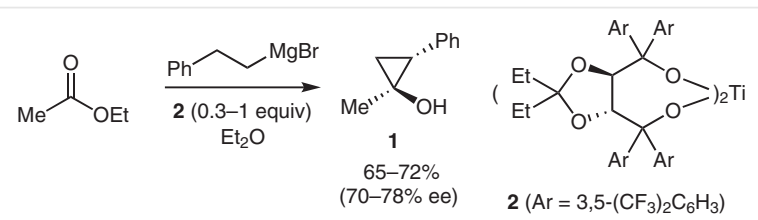

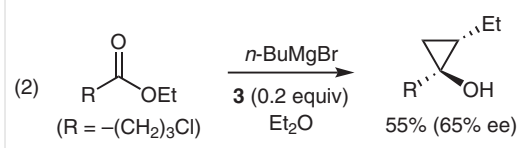

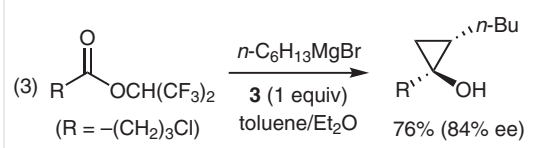<smiles>CCCCOC(OC(O[Ge])(c1ccccc1)c1ccccc1)C1OC(C)(C)O[C@H]1c1ccccc1</smiles>

(4)

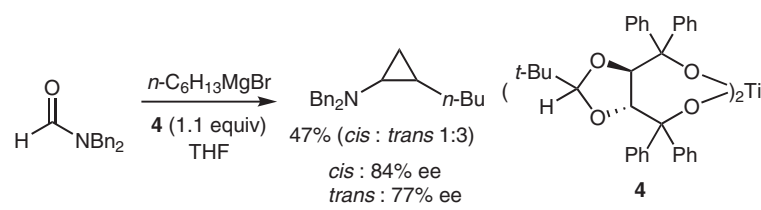

Scheme 1 Best results for the cyclopropanation of carboxylic acid derivatives

The proposed mechanism (Scheme 2, left) involves the insertion of the nitrile moiety into titanacyclopropane $\mathbf{A}$ to furnish intermediate $\mathbf{B}$. The spontaneous cyclization can be explained by the formation of intermediate $\mathbf{C}$, followed by an intramolecular nucleophilic addition affording spirocyclic compound $\mathbf{D} .{ }^{22}$ The addition of Grignard reagent closes the catalytic cycle. This sequence is very similar to that proposed for the Kulinkovich reaction (Scheme 2, right), ${ }^{23}$ and these cyanoesters give us the opportunity to investigate the enantioselective variant. In the same time, a methodology will be developed to directly evaluate ligands in cyclopropanation without requiring the prior preparation of titanium complexes.

The cyclopropanation of ethyl 3-cyanopropanoate (5a) with $n$-BuMgBr was selected as a model reaction for this study (Table 1 ). When $n$-BuMgBr was added to a mixture of nitrile $\mathbf{5 a}$ and a stoichiometric amount of $\mathrm{Ti}(\mathrm{OiPr})_{4}$ in $\mathrm{Et}_{2} \mathrm{O}$, spirocyclic amide $\mathbf{6 a}$ was obtained as a separable mixture of two diastereoisomers in 82:18 proportion in favor of the cis isomer (entry 1). ${ }^{24}$ When the reaction was performed with only 0.2 equiv of titanium isopropoxide, the yield and the diastereoselectivity were quite similar (entry 2), in accordance to previous results. ${ }^{21}$ The reaction was next studied with Taddol $7\left(\mathrm{LH}_{2}\right)$ as ligand. ${ }^{25}$ When the spirotitanate 8 $\left(\mathrm{L}_{2} \mathrm{Ti}\right)$, prepared from Taddol 7 and $\mathrm{Ti}(\mathrm{OiPr})_{4}$ in a 2:1 ratio, ${ }^{26}$ was used instead of $\mathrm{Ti}(\mathrm{OiPr})_{4}$, a significant decrease in the yield was observed, and the two diastereoisomers were obtained with a low enantioinduction ( $14 \%$ and $30 \%$ ee, entry 3 ). The use of a catalytic amount ( 0.2 equiv) of this complex resulted in similar low yields, but lower enantioselectivities (entry 4). The complex LTi( $\mathrm{OiPr})_{2}(\mathbf{3})$, prepared in situ from an equimolar mixture of spirotitanate $\mathbf{8}\left(\mathrm{L}_{2} \mathrm{Ti}\right)$ and $\mathrm{Ti}(\mathrm{OiPr})_{4}$ (Method A), ${ }^{27}$ afforded lactam 6 in significantly higher yields and diastereoselectivities, and the major diastereoisomer was obtained with $32 \%$ ee (entry 5 ). These results were found to be less satisfactory when this same complex was used in catalytic amount (entry 6). To perform a rapid screening of the ligand, the complex was also prepared by simply mixing Taddol $\mathbf{7}$ and titanium isopropoxide in $\mathrm{Et}_{2} \mathrm{O}$ (Method B). ${ }^{27,28}$ Taking into account the use of a larger amount of Grignard reagent to deprotonate the liberated

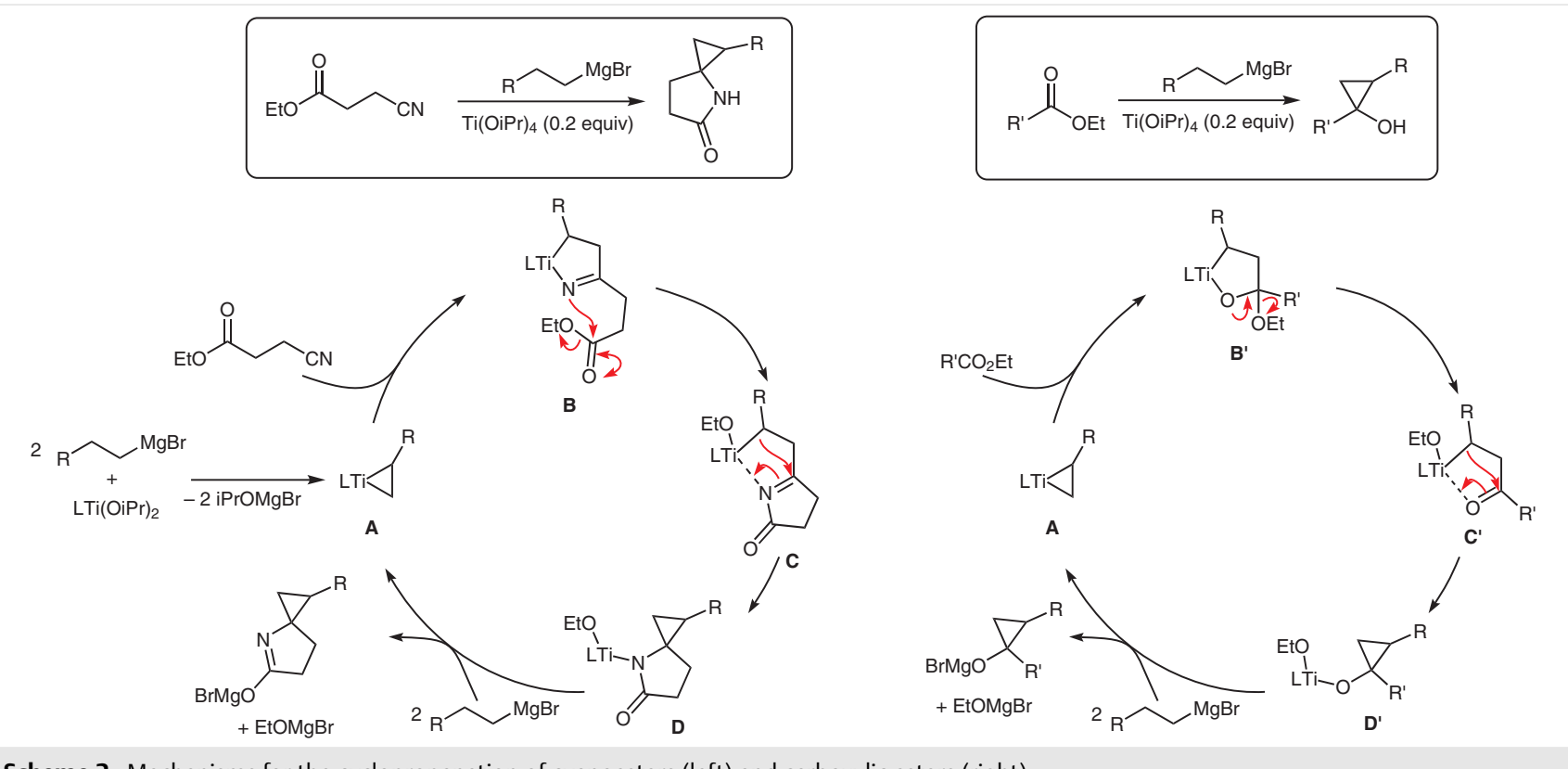

Scheme 2 Mechanisms for the cyclopropanation of cyanoesters (left) and carboxylic esters (right) 
Table 1 Optimization of the Conditions for the Cyclopropanation of $\mathbf{5}^{\mathrm{a}}$

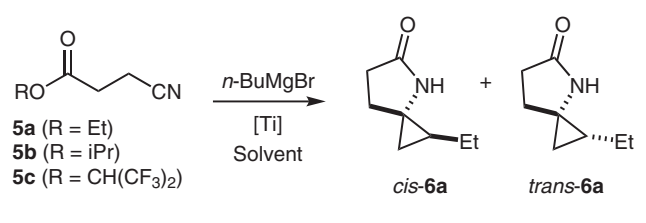

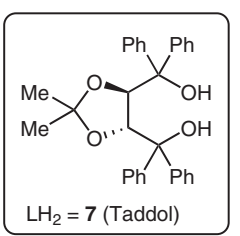

Methods of preparation of the complex $\mathrm{LTi}(\mathrm{OiPr})_{2}$

(A) $0.5 \mathrm{~L}_{2} \mathrm{Ti}+0.5 \mathrm{Ti}(\mathrm{OiPr})_{4} \longrightarrow \mathrm{LTi}(\mathrm{OiPr})_{2}$

(B) $\mathrm{LH}_{2}+\mathrm{Ti}(\mathrm{OiPr})_{4} \quad \longrightarrow \mathrm{LTi}(\mathrm{OiPr})_{2}+2 \mathrm{iPrOH}$

(C) $\mathrm{LH}_{2}+\mathrm{MeTi}(\mathrm{OiPr})_{3} \longrightarrow \mathrm{LTi}(\mathrm{OiPr})_{2}+\mathrm{MeH}+\mathrm{iPrOH}$

\begin{tabular}{|c|c|c|c|c|c|}
\hline Entry & Conditions & Yield (\%) & cis-6a/trans-6a & ee cis-6a & ee trans-6a \\
\hline 1 & $\mathrm{Ti}(\mathrm{OiPr})_{4}$ (1 equiv) in $\mathrm{Et}_{2} \mathrm{O}$ & 74 & $82: 18$ & - & - \\
\hline 2 & $\mathrm{Ti}(\mathrm{OiPr})_{4}\left(0.2\right.$ equiv) in $\mathrm{Et}_{2} \mathrm{O}$ & 76 & $85: 15$ & - & - \\
\hline 3 & $\mathrm{TiL}_{2}$ (1 equiv) in $\mathrm{Et}_{2} \mathrm{O}$ & 31 & $87: 13$ & 14 & 30 \\
\hline 4 & $\mathrm{TiL}_{2}$ (0.2 equiv) in $\mathrm{Et}_{2} \mathrm{O}$ & 30 & $86: 14$ & 6 & 14 \\
\hline 5 & $\mathrm{LTi}(\mathrm{OiPr})_{2}(1 \text { equiv })^{\mathrm{b}}$ in $\mathrm{Et}_{2} \mathrm{O}$ & 81 & $95: 5$ & 32 & 36 \\
\hline 6 & $\mathrm{LTi}(\mathrm{OiPr})_{2}(0,2 \text { equiv })^{\mathrm{b}}$ in $\mathrm{Et}_{2} \mathrm{O}$ & 38 & $87: 13$ & 20 & 36 \\
\hline 7 & $\mathrm{LTi}(\mathrm{OiPr})_{2}(1 \text { equiv })^{\mathrm{C}}$ in $\mathrm{Et}_{2} \mathrm{O}$ & 68 & $95: 5$ & 30 & 36 \\
\hline 8 & $\mathrm{LTi}(\mathrm{OiPr})_{2}(0.2 \text { equiv })^{\mathrm{c}}$ in $\mathrm{Et}_{2} \mathrm{O}$ & 64 & $87: 13$ & 32 & 45 \\
\hline 9 & $\mathrm{LTi}(\mathrm{OiPr})_{2}(0.2 \text { equiv })^{\mathrm{d}}$ in $\mathrm{Et}_{2} \mathrm{O}$ & 64 & $85: 15$ & 27 & 39 \\
\hline 10 & $\mathrm{LTi}(\mathrm{OiPr})_{2}(0.2 \text { equiv })^{\mathrm{e}}$ in $\mathrm{Et}_{2} \mathrm{O}$ & 68 & $89: 11$ & 28 & 50 \\
\hline 11 & $\mathrm{LTi}(\mathrm{OiPr})_{2}(0.2 \text { equiv })^{\mathrm{c}}$ in THF & 18 & $74: 26$ & 8 & $<5$ \\
\hline 12 & $\mathrm{LTi}(\mathrm{OiPr})_{2}(0.2 \text { equiv })^{\mathrm{c}}$ in toluene & 50 & $85: 15$ & 27 & 42 \\
\hline 13 & $\mathrm{LTi}(\mathrm{OiPr})_{2}(0.2 \text { equiv })^{\mathrm{C}}$ in $\mathrm{CH}_{2} \mathrm{Cl}_{2}$ & 66 & $87: 13$ & 29 & 31 \\
\hline $14^{\mathrm{f}}$ & $\mathrm{LTi}(\mathrm{OiPr})_{2}(0.2 \text { equiv })^{\mathrm{c}}$ in $\mathrm{Et}_{2} \mathrm{O}$ & 48 & $90: 10$ & 28 & 42 \\
\hline $15^{9}$ & $\mathrm{LTi}(\mathrm{OiPr})_{2}(0.2 \text { equiv })^{\mathrm{c}}$ in $\mathrm{Et}_{2} \mathrm{O}$ & 41 & $92: 8$ & 30 & 48 \\
\hline
\end{tabular}

a Reaction conditions: $\mathbf{5 a}(1 \mathrm{mmol})$, titanium complex, $n-\mathrm{BuMgBr}\left(1 \mathrm{M}\right.$ in $\left.\mathrm{Et}_{2} \mathrm{O}\right)$, r.t., in the indicated solvent, unless noted.

${ }^{b}$ Method A: $\mathrm{LTi}(\mathrm{OiPr})_{2}$ prepared in situ from $\mathrm{TiL}_{2}$ ( $n / 2$ equiv) and $\mathrm{Ti}(\mathrm{OiPr})_{4}$ ( $n / 2$ equiv).

${ }^{c}$ Method B: $\mathrm{LTi}(\mathrm{OiPr})_{2}$ prepared in situ from $\mathrm{Ti}(\mathrm{OiPr})_{4}$ ( $n$ equiv) and Taddol ( $n$ equiv). Since iPrOH ( $2 n$ equiv) is released, the amount of $\mathrm{Grignard}$ reagent was adjusted to also deprotonate it.

${ }^{d}$ Method C: $\mathrm{LTi}(\mathrm{OiPr})_{2}$ prepared in situ from MeTi(OiPr) ${ }_{3}$ ( $n$ equiv) and Taddol (n equiv). Since iPrOH ( $n$ equiv) is released, the amount of Grignard reagent was adjusted to also deprotonate it.

e $\mathrm{ClTi}(\mathrm{OiPr})_{3}$ was used instead of $\mathrm{Ti}(\mathrm{OiPr})_{4}$.

${ }^{f}$ Cyanoester $\mathbf{5 b}$ was used.

9 Cyanoester $5 \mathrm{c}$ was used.

isopropanol, the results (diastereoselectivity and enantioselectivity) are very close to those obtained with preformed catalyst 3 (entries 7 vs. 5). This result shows that the catalytic species would be the same, and that the isopropanol generated during the formation of the complex has only minor influence on the course of the reaction. This method can be transposed catalytically without incidence (entry 8 ). The results are similar when $\mathbf{3}$ was generated from $\mathrm{MeTi}(\mathrm{OiPr})_{3}\left(\right.$ Method C) or from $\mathrm{ClTi}(\mathrm{OiPr})_{3}$ (entries 9 and 10$)$.

The influence of the solvent was next evaluated. Whereas toluene or dichloromethane give quite similar results to those obtained in $\mathrm{Et}_{2} \mathrm{O}$, the use of THF led to a strong decrease in performance, suggesting a dramatic modification of the reaction outcome (entries 11-13). Since it was shown that the ester alkoxy group has a strong influence on the enantioselectivity of the cyclopropanation of carboxylic esters, ${ }^{19 b}$ cyanoesters $\mathbf{5 b}$ and $\mathbf{5 c}$, bearing isopropyl and hexafluoroisopropyl moieties, respectively, were also used, but showed here only marginal improvements, with a yield erosion (entries 14 and 15 vs. 8).

In conclusion for this study, spirotitanate $\mathbf{8}$ was shown to be less efficient than $\mathrm{LTi}(\mathrm{OiPr})_{2}$ (3), as observed by Kulinkovich for the cyclopropanation of esters, ${ }^{19 a}$ and in contrast with the results obtained for the cyclopropanation of amides, in which spirotitanate $\mathbf{8}$ give comparable yields and even better enantioselectivities than $\mathbf{3}^{20}$

The competing reactivities of $\mathrm{LTi}(\mathrm{OiPr})_{2}(\mathbf{3})$ and $\mathrm{Ti}(\mathrm{OiPr})_{4}$ were next compared by modifying the amount of Taddol $\mathbf{7}$ to evaluate the effect of remaining titanium isopropoxide on the enantioselectivity; the results are presented in Figure 1. 


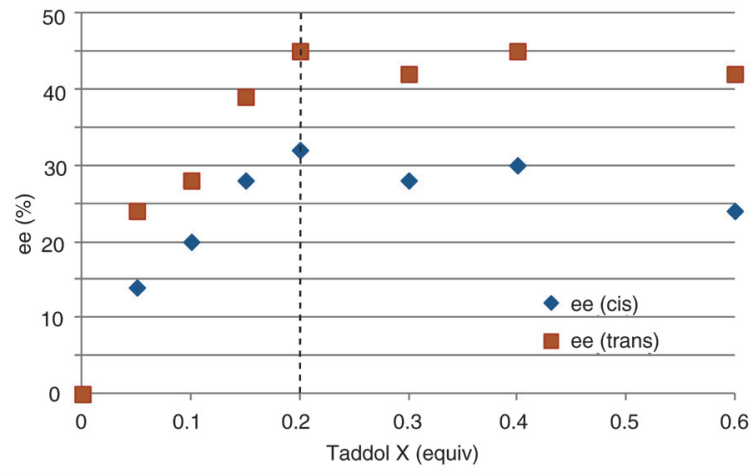

Figure 1 Enantiomeric excesses of cis-6a and trans-6a relative to the amount of Taddol 7 used; the amount of $\mathrm{Ti}(\mathrm{OiPr})_{4}$ was kept constant ( 0.2 equiv) and the amount of Grignard reagent was adjusted to deprotonate the liberated isopropanol

As clearly shown in the Figure 1, when the amount of ligand was less than the amount of metal, the enantioselectivity was essentially proportional to the amount of ligand. After the equivalence point, the enantioselectivity remained quite stable, with a slight decrease when the amount of ligand was threefold the amount of titanium isopropoxide. This study indicates that the active complex is a 1:1 complex between the ligand and the metal, which is consistent with the proposition made for the cyclopropanation of carboxylic esters. In addition, the cyclopropanation with 3 operates at a similar rate to that with $\mathrm{Ti}(\mathrm{OiPr})_{4}$. Together, these results demonstrate the similar reactivity between the preformed $\mathrm{LTi}(\mathrm{OiPr})_{2}$ (method A) and the complex prepared in situ from Taddol and $\mathrm{Ti}(\mathrm{OiPr})_{4}$ (method $\mathrm{B}$ ).

Since the use of 3, generated from Taddol 7 and $\mathrm{Ti}(\mathrm{OiPr})_{4}$ in the reaction media, gives similar results to those obtained using method $\mathrm{A}$ in the above cyclopropanation reaction, a screening of a large array of ligands was carried out using method B (Table 2 and Figure 2). First, several Taddol derivatives 9-17 were prepared and used in the cyclopropanation reaction. In no case, the reaction outcome has been improved compared to that with Taddol 7 (entries 2-8 vs. 1). Particularly, the increase in the steric bulk around the metal results in a decrease in the yield of the reaction (entry 5). The presence of a methoxy group on the ortho position of the aromatic rings (entry 8), or replacement of the dioxolane moiety by methoxy groups (entry 9 ) led to a loss of enantioselectivity, which could be explained by a modification of the coordination around the metal induced by the methoxy groups. Interestingly, diol $\mathbf{1 7}$ afforded a total diastereoselectivity in favor of the cis isomer. The use of Binol (19) was found to be inefficient in the case of amides, ${ }^{20}$ and this is also the case here (entry 12). This could be the consequence of the formation of aggregate complexes in the reaction media. ${ }^{29}$ The 3,3'-disubstituted Binol 20, which is less prone to the formation of aggregates, should be more efficient than Binol, but unfortunately, the same reactivity pro- file was observed (entry 13 ). The chimeric diol 21, ${ }^{30}$ bearing the axial chirality of Binol and the diphenyl methanol structure of Taddol, was also found to be less efficient than Taddol 7 (entry 14). With the aim to add an extra coordination site on titanium by the presence of a nitrogen atom, aminodiols 22-27 $\mathbf{2 7}^{31}$ were used as ligands. Unfortunately, almost no enantioselectivity was observed with these ligands (entries 15-20). Finally, despite efforts to increase the enantioselectivity of the cyanoester cyclopropanation reaction, the parent Taddol ligand 7 afforded the best results to date.

Table 2 Ligand Screening in the Cyclopropanation of $\mathbf{5 a}$ (see also Figure 2)

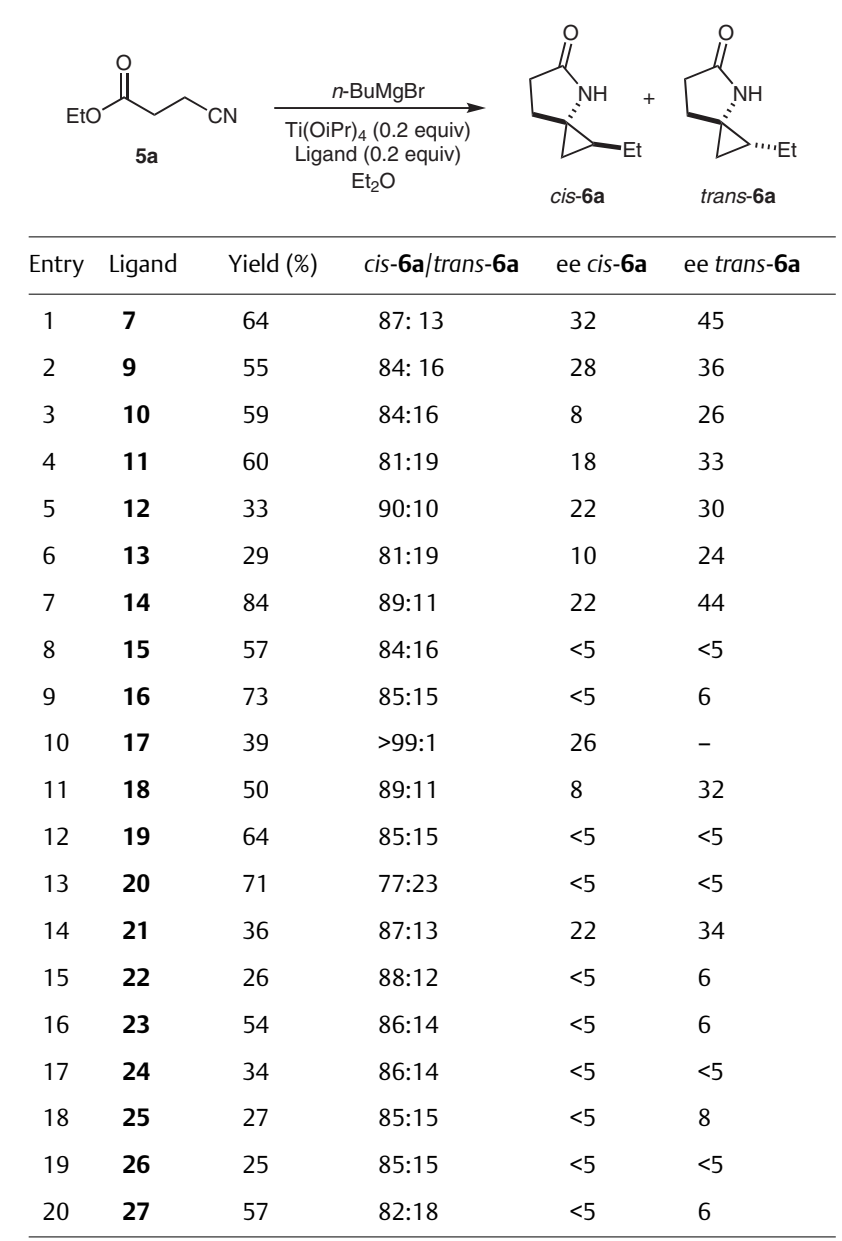

The scope of the reaction was next evaluated with other Grignard reagents by using the complex generated in situ from Taddol 7 and $\mathrm{Ti}(\mathrm{OiPr})_{4}$. The most significant examples are presented in Table 3.

With all the Grignard reagents used, the yields and the diastereoselectivities remain more or less constant when comparing the reaction with $\mathrm{Ti}(\mathrm{OiPr})_{4}$ alone or in the presence of Taddol 7. With one exception, the diastereoselectivity is greatly in favor of the cis isomer (Table 3, entries 1- 


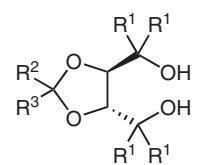

$7\left(R^{1}=P h, R^{2}=R^{3}=M e\right)$

$9\left(R^{1}=P h, R^{2}=R^{3}=E t\right)$

$10\left(\mathrm{R}^{1}=\mathrm{Ph}, \mathrm{R}^{2}=p-\mathrm{MeOC}_{6} \mathrm{H}_{4}, \mathrm{R}^{3}=\mathrm{H}\right)$

$11\left(R^{1}=3,5-M_{2} C_{6} H_{3}, R^{2}=R^{3}=M e\right)$

$12\left(R^{1}=1\right.$-Naphth, $\left.R^{2}=R^{3}=\mathrm{Me}\right)$

$13\left(R^{1}=3,5-\left(C_{3}\right)_{2} \mathrm{C}_{6} \mathrm{H}_{3}, \mathrm{R}^{2}=\mathrm{R}^{3}=\mathrm{Me}\right)$

$14\left(\mathrm{R}^{1}=p-\mathrm{MeOC}_{6} \mathrm{H}_{4}, \mathrm{R}^{2}=\mathrm{R}^{3}=\mathrm{Me}\right)$

$15\left(R^{1}=o-M_{e O C} \mathrm{H}_{4}, R^{2}=R^{3}=M e\right)$<smiles>[R]c1cc2ccccc2c(-c2c(O)c([R])cc3ccccc23)c1O</smiles>

$19(\mathrm{R}=\mathrm{H})$

$20(\mathrm{R}=\mathrm{Ph})$<smiles>[R]c1cc([R])c(O)c(CN2CCCC2C([R])([R])O)c1</smiles>

$22\left(R^{1}=R^{2}=H\right)$

$23\left(R^{1}=P h, R^{2}=H\right)$

$24\left(\mathrm{R}^{1}=\mathrm{Ph}, \mathrm{R}^{2}=t-\mathrm{Bu}\right)$

$$
\text { OR }
$$

$16\left(R^{1}=M e, R^{2}=H\right)$

$17\left(R^{1}=H, R^{2}=M e\right)$

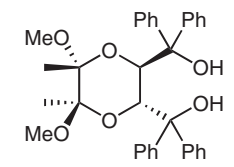

18 (TARTROL)

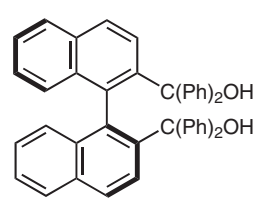

21<smiles>[R][C@H](CO)NCc1ccccc1O</smiles>

$25(\mathrm{R}=\mathrm{Me})$

$26(\mathrm{R}=s-\mathrm{Bu})$

$27(R=B n)$
Figure 2 Ligands used in the cyclopropanation of $\mathbf{5 a}$ (see Table 2)

12). When homoallylic Grignard reagent was used, the trans isomer of $\mathbf{6 g}$ was formed (entries 13 and 14). The enantiomeric excesses observed for the main diastereoisomer never exceeded $32 \%$.

This persistent low enantioselectivity observed with cyanoesters, compared with those obtained with carboxylic esters (up to $84 \%$ ee) using the same kind of complex, seems to indicate several alternative pathways for the cyclopropanation of cyanoesters. First, the insertion step is certainly nonselective, in contrast to what it is generally admitted for the Kulinkovich reaction, ${ }^{23 b, 32}$ and two metallacycle intermediates B1 and B2 could be obtained (Scheme 3). ${ }^{33}$ This assumption is supported by the fact that nitrile $\mathbf{2 8}$, used under the same reaction conditions, gives two isomeric ketones $\mathbf{2 9}$ and $\mathbf{3 0}$ derived from B1 and B2, respectively, after acidic hydrolysis, which demonstrates that the insertion step is not selective with nitriles (Scheme 3). ${ }^{34}$

Since the diastereoisomeric ratios are always very similar, irrespective of the achiral or chiral conditions used, this step is probably weakly dependent on the nature of the titanium complex. During the diastereoselective cyclopropanation step, the titanium atom moves out of the plane of the imine moiety, via the putative transition states $\mathbf{C}-\mathbf{1}$ or $\mathbf{C}-$ 2 (Scheme 4). The bulky titanium complex would hinder
Table 3 Cyclopropanation of $\mathbf{5 a}$ with Grignard Reagents

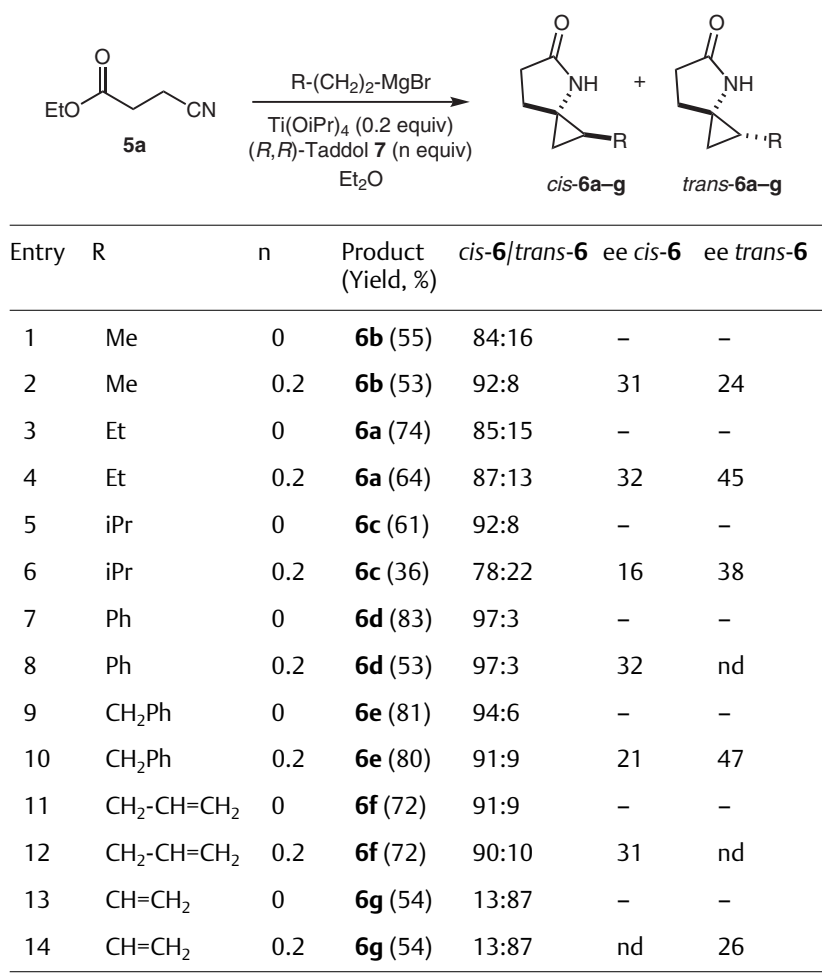

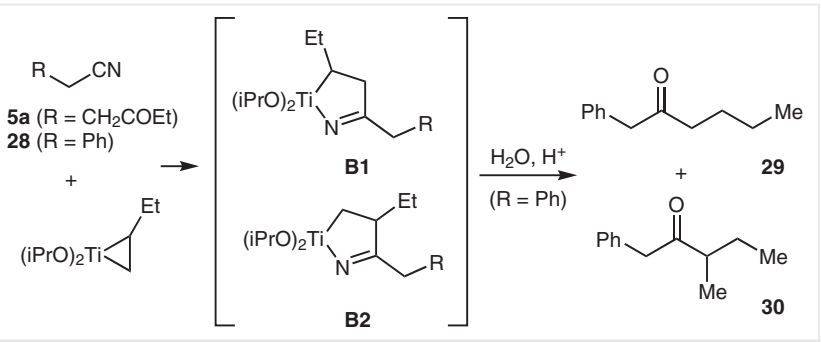

Scheme 3 Hydrolytic products derived from the insertion step of nitrile $\mathbf{2 8}$

one side of the future cyclopropane and the presence of substituents at the $a$ or $b$ position would favor the path $i$ via C-1 leading to the formation of the cis isomer D-1. Similarly, for substitution at $c$ or $d$ positions, the path $i i$ would be favored. ${ }^{35}$

The particular case of the 'abnormal' stereochemistry for $\mathbf{6 g}$ can be explained by taking into account the fact that an allyltitanium intermediate was obtained. The sixcentered ring contraction of intermediate $\mathbf{C}-\mathbf{3}$ would occur easily (Scheme 5) leading mainly to the formation of the trans isomer. ${ }^{36}$ 


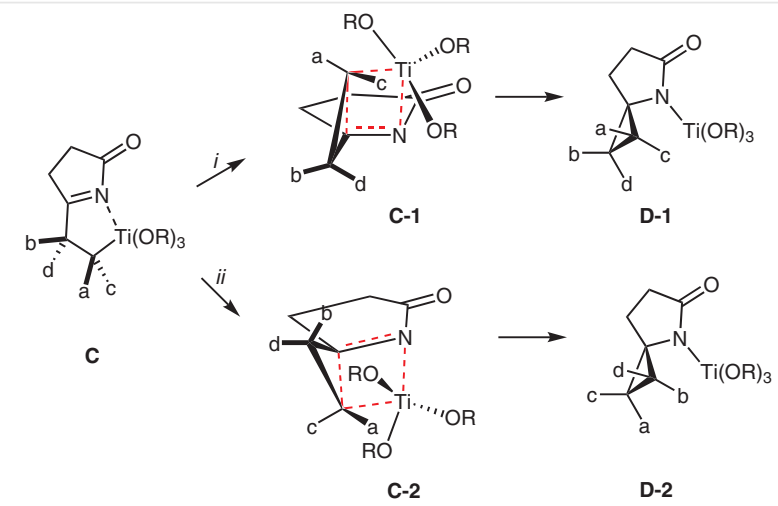

Scheme 4 Pathways explaining the diastereoselectivity observed for 6a-f

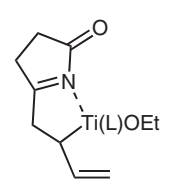

C

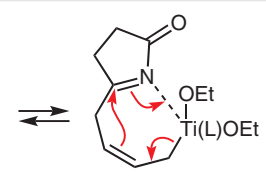

C-3

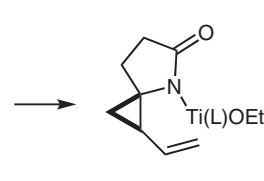

D-3
Scheme 5 Pathway explaining the diastereoselectivity observed for $\mathbf{6 g}$

In summary, the evaluation of different complexes derived from Taddol and $\mathrm{Ti}(\mathrm{OiPr})_{4}$ has shown that the $\mathrm{LTi}(\mathrm{OiPr})_{2}$ species, generated directly in the reaction solvent, present a similar reactivity to that of the preformed complex and a better activity than the spirotitanate $\mathrm{TiL}_{2}$. With this method, a rapid screening of ligands was carried out, but none of them surpassed the parent Taddol, with a $32 \%$ ee for the major diastereoisomer, which remains the best enantioselectivity reported to date for this reaction. The methodology used here can be applied to other Ti-catalyzed reactions to facilitate the screening of ligands; studies in this direction are in progress in our laboratory.

Experiments involving Grignard reagents were carried out under $\mathrm{N}_{2}$ atmosphere. $\mathrm{Et}_{2} \mathrm{O}, \mathrm{THF}, \mathrm{CH}_{2} \mathrm{Cl}_{2}$ and toluene were purified by passing through neutral alumina columns under nitrogen. The Grignard reagents were prepared in anhydrous $\mathrm{Et}_{2} \mathrm{O}$ using the standard method from the appropriate bromide precursors and Mg turnings. All Grignard reagents were titrated before use according to the B. E. Love method. ${ }^{37}$ Analytical TLC were performed on Alugram SIL G/UV254 silica gel sheets (Macherey-Nagel) by using phosphomolybdic acid solution. Column chromatography was carried out using silica gel 60 (0.040-0.063 mm) from Merck.

Melting points were determined with a Büchi B-540 melting point apparatus and are uncorrected. ${ }^{1} \mathrm{H}$ and ${ }^{13} \mathrm{C}$ NMR spectra were recorded with a Bruker DPX-200 or Bruker AC-400 spectrometer. Chemical shifts $(\delta)$ are expressed in ppm units, relative to the residual solvent peak. Coupling constants are given in $\mathrm{Hz}$. The multiplicities are reported as: singlet $(\mathrm{s})$, doublet $(\mathrm{d})$, triplet $(\mathrm{t})$, quadruplet $(\mathrm{q})$, multiplet (m), and broad signal (br s). IR spectra were obtained with a PerkinElmer Spectrum One spectrometer on a single-reflection diamond ATR unit. High-resolution mass spectra were recorded with a Waters Micromass GCT Premier spectrometer. The enantiomeric excesses were determined with a Waters e2695 HPLC apparatus using a Chiralcel OD column. A mixture of hexane/iPrOH (95:5) was used as solvent at $1 \mathrm{~mL} \cdot \mathrm{min}^{-1}$ flow. UV detection was used. Both the wavelengths and the retention times are specified for each spirolactams below. The following compounds have been previously reported: $5 \mathbf{a}-\mathbf{b},{ }^{21} \mathbf{6 a},{ }^{21} \mathbf{6 e},{ }^{21}$ $\mathbf{6 g},{ }^{21} 7,{ }^{38} 8,{ }^{27} 9,{ }^{20} 10,{ }^{39} 11,{ }^{40} 12,{ }^{41} 13,{ }^{20} 14,{ }^{42} 16,{ }^{42} 17,{ }^{43} 18,{ }^{44} \mathbf{2 0}^{45}, \mathbf{2 1},{ }^{30}$ 22, ${ }^{31 \mathrm{a}} \mathbf{2 3},{ }^{46} \mathbf{2 4},{ }^{47} \mathbf{2 5}-\mathbf{2 7},{ }^{31 \mathrm{a}}$

\section{1,1,1,3,3,3-Hexafluoropropan-2-yl 3-Cyanopropanoate (5c)}

To a solution of glutamic acid $(1.47 \mathrm{~g}, 10 \mathrm{mmol})$ in $2 \mathrm{M}$ aq. $\mathrm{NaOH}$ solution $(10 \mathrm{~mL})$ was added portionwise trichloroisocyanuric acid $(1.56 \mathrm{~g}$, $6.7 \mathrm{mmol}$ ) at $0{ }^{\circ} \mathrm{C}$. The resulting mixture was stirred for $1 \mathrm{~h}$ at r.t. then $3 \mathrm{M}$ aq. $\mathrm{HCl}$ solution $(10 \mathrm{~mL})$ was added and the reaction was stirred for $10 \mathrm{~min}$. The mixture was extracted with $\mathrm{Et}_{2} \mathrm{O}(3 \times 20 \mathrm{~mL})$ and the combined organic phases were washed with brine, dried over $\mathrm{MgSO}_{4}$, filtered and the solvent was removed in vacuo to give 3-cyanopropanoic acid.

Yield: $490 \mathrm{mg}$ (49\%); colorless oil.48

${ }^{1} \mathrm{H}$ NMR $\left(\mathrm{D}_{2} \mathrm{O}, 200 \mathrm{MHz}\right): \delta=2.69-2.81\left(\mathrm{~m}, 4 \mathrm{H}, \mathrm{CH}_{2}\right)$.

${ }^{13} \mathrm{C}$ NMR $\left(\mathrm{D}_{2} \mathrm{O}, 50 \mathrm{MHz}\right): \delta=176.9(\mathrm{C}=\mathrm{O}), 120.7(\mathrm{CN}), 29.0\left(\mathrm{CH}_{2} \mathrm{C}=\mathrm{O}\right)$, $12.4\left(\mathrm{CH}_{2} \mathrm{CN}\right)$.

To a solution of 3-cyanopropanoic acid (396 mg, $4 \mathrm{mmol}$ ) in $\mathrm{CH}_{2} \mathrm{Cl}_{2}$ $(10 \mathrm{~mL})$ was added thionyl chloride $(0.32 \mathrm{~mL}, 4.8 \mathrm{mmol})$ at r.t. The reaction mixture was stirred for $2 \mathrm{~h}$ at $40{ }^{\circ} \mathrm{C}$ then volatiles were removed in vacuo and 1,1,1,3,3,3-hexafluoropropan-2-ol (5 mL) was added. The resulting mixture was stirred for a further $2 \mathrm{~h}$ at $60^{\circ} \mathrm{C}$. After removal of volatiles under reduced pressure, purification by flash chromatography (90:10 to 80:20, cyclohexane/EtOAc) afforded 5c.

Yield: $972 \mathrm{mg}$ (65\%); colorless liquid; $R_{f}=0.33$ (82:18, cyclohexane/EtOAc).

IR (neat): 2976, 1784, 1385, 1289, 1197, 1110, $907 \mathrm{~cm}^{-1}$.

${ }^{1} \mathrm{H} \mathrm{NMR}\left(\mathrm{CDCl}_{3}, 400 \mathrm{MHz}\right): \delta=5.79($ hept $J=5.9 \mathrm{~Hz}, 1 \mathrm{H}, \mathrm{CH}), 2.92(\mathrm{t}$, $\left.J=7.2 \mathrm{~Hz}, 2 \mathrm{H}, \mathrm{CH}_{2} \mathrm{CN}\right), 2.72\left(\mathrm{t}, J=7.2 \mathrm{~Hz}, 2 \mathrm{H}, \mathrm{CH}_{2} \mathrm{C}=\mathrm{O}\right)$.

${ }^{13} \mathrm{C} \mathrm{NMR}\left(\mathrm{CDCl}_{3}, 100 \mathrm{MHz}\right): \delta=167.4(\mathrm{C}=\mathrm{O}), 120.2(\mathrm{q}, J=283 \mathrm{~Hz}, 2 \mathrm{C}$, $\left.\mathrm{CF}_{3}\right), 117.3(\mathrm{CN}), 67.1$ (hept, $\left.J=35 \mathrm{~Hz}, \mathrm{CH}\right), 29.3\left(\mathrm{CH}_{2} \mathrm{C}=\mathrm{O}\right), 12.7$ $\left(\mathrm{CH}_{2} \mathrm{CN}\right)$.

${ }^{19} \mathrm{~F} \mathrm{NMR}\left(\mathrm{CDCl}_{3}, 376 \mathrm{MHz}\right): \delta=-73.4\left(\mathrm{~d}, J=5.9 \mathrm{~Hz}, 6 \mathrm{~F}, \mathrm{CF}_{3}\right)$. HRMS (ESI+): $m / z\left[\mathrm{M}+\mathrm{Na}^{+}\right]$calcd for $\mathrm{C}_{7} \mathrm{H}_{5} \mathrm{~F}_{6} \mathrm{NO}_{2} \mathrm{Na}$ : 272.0117; found: 272.0120 .

\section{Asymmetric Synthesis of Spirolactams 6a-g; General Procedure}

To a solution of $\mathrm{Ti}(\mathrm{OiPr})_{4}(60 \mu \mathrm{L}, 0.2 \mathrm{mmol})$ in $\mathrm{Et}_{2} \mathrm{O}(10 \mathrm{~mL})$ was added Taddol 7 (93 mg, $0.2 \mathrm{mmol})$. The resulting mixture was stirred for 10 min, then 5a $(127 \mathrm{mg}, 1 \mathrm{mmol})$ was added. The the appropriate Grignard reagent $(2.5 \mathrm{mmol})$ was added dropwise over $1 \mathrm{~h}$. A gray precipitate readily appeared and the mixture became brown and turbid. The reaction mixture was stirred for an additional $1 \mathrm{~h}$ and $1 \mathrm{M}$ aq. $\mathrm{HCl}$ solution $(2 \mathrm{~mL})$ was added. The layers were separated and the aqueous phase was extracted with EtOAc $(2 \times 5 \mathrm{~mL})$. The combined organic layers were washed with brine, dried over $\mathrm{MgSO}_{4}$, filtered and the solvents were removed in vacuo. The crude residue was purified by flash chromatography to afford the expected spirolactam $\mathbf{6}$ and to recover the Taddol 7. 


\section{1-Ethyl-4-azaspiro[2.4]heptan-5-one (6a) ${ }^{21}$}

Obtained according to the general procedure using $n$-BuMgBr (prepared from 1-bromobutane in $\mathrm{Et}_{2} \mathrm{O},[\mathrm{C}]=1.24 \mathrm{M}$ ). Purification by flash chromatography (100:0 to 90:10, EtOAc/iPrOH) afforded $\mathbf{6 a}$ as a mixture of diastereoisomers (87:13, $89 \mathrm{mg}, 64 \%$ ).

Minor diastereoisomer isolated as an orange oil; $R_{f}=0.38(100 \%$, EtOAc); $t_{R}=8.8,11.2 \mathrm{~min}(45 \% \mathrm{ee})$.

IR (neat): 3201, 2959, 2874, 1687, 1460, 1365, $1283 \mathrm{~cm}^{-1}$.

${ }^{1} \mathrm{H} \mathrm{NMR}\left(\mathrm{CDCl}_{3}, 400 \mathrm{MHz}\right): \delta=6.80($ br s, $1 \mathrm{H}, \mathrm{NH}), 2.54-2.38(\mathrm{~m}, 2 \mathrm{H}$, $\mathrm{CH}_{2} \mathrm{C}=\mathrm{O}$ ), 2.17 (ddd, $J=12.7,9.2,7.9 \mathrm{~Hz}, 1 \mathrm{H}, \mathrm{CH}_{2} \mathrm{CH}_{2} \mathrm{C}=\mathrm{O}$ ), 2.01 (ddd, $\left.J=12.7,9.1,5.9 \mathrm{~Hz}, 1 \mathrm{H}, \mathrm{CH}_{2} \mathrm{CH}_{2} \mathrm{C}=0\right), 1.38-1.29\left(\mathrm{~m}, 2 \mathrm{H}, \mathrm{CH}_{2} \mathrm{CH}_{3}\right)$, 0.99 (t, $\left.J=7.3 \mathrm{~Hz}, 3 \mathrm{H}, \mathrm{CH}_{3}\right), 0.81-0.71\left(\mathrm{~m}, 2 \mathrm{H}, \mathrm{CH}, \mathrm{CH}_{2}\right), 0.45-0.38$ (m, $1 \mathrm{H}, \mathrm{CH}_{2}$ ).

${ }^{13} \mathrm{C} \mathrm{NMR}\left(\mathrm{CDCl}_{3}, 100 \mathrm{MHz}\right): \delta=178.6(\mathrm{C}=0), 43.3(\mathrm{C}), 31.1\left(\mathrm{CH}_{2} \mathrm{C}=0\right)$, $30.7\left(\mathrm{CH}_{2} \mathrm{CH}_{2} \mathrm{C}=\mathrm{O}\right), 24.6(\mathrm{CH}), 22.8\left(\mathrm{CH}_{2} \mathrm{CH}_{3}\right), 16.5\left(\mathrm{CH}_{2}\right), 13.9\left(\mathrm{CH}_{3}\right)$.

HRMS (ESI+): $m / z\left[\mathrm{M}+\mathrm{Na}^{+}\right]$calcd for $\mathrm{C}_{8} \mathrm{H}_{13} \mathrm{NONa}$ : 162.0889; found: 162.0896.

Major diastereoisomer isolated as a pale-yellow oil; $R_{f}=0.27(100 \%$, EtOAc); $t_{R}=12.1,15.6 \mathrm{~min}(32 \% e e)$.

IR (neat): 3213, 2959, 2874, 1687, 1460, 1357, $1240 \mathrm{~cm}^{-1}$.

${ }^{1} \mathrm{H} \mathrm{NMR}\left(\mathrm{CDCl}_{3}, 400 \mathrm{MHz}\right): \delta=7.17$ (br s, $\left.1 \mathrm{H}, \mathrm{NH}\right), 2.55-2.36(\mathrm{~m}, 2 \mathrm{H}$, $\mathrm{CH}_{2} \mathrm{C}=\mathrm{O}$ ), 2.18 (ddd, $J=12.9,9.7,7.4 \mathrm{~Hz}, 1 \mathrm{H}, \mathrm{CH}_{2} \mathrm{CH}_{2} \mathrm{C}=\mathrm{O}$ ), 1.90 (ddd, $\left.J=12.9,9.7,5.8 \mathrm{~Hz}, 1 \mathrm{H}, \mathrm{CH}_{2} \mathrm{CH}_{2} \mathrm{C}=0\right), 1.41-1.28\left(\mathrm{~m}, 1 \mathrm{H}, \mathrm{CH}_{2} \mathrm{CH}_{3}\right)$, $1.20-1.09\left(\mathrm{~m}, 1 \mathrm{H}, \mathrm{CH}_{2} \mathrm{CH}_{3}\right), 0.96\left(\mathrm{t}, J=7.3 \mathrm{~Hz}, 3 \mathrm{H}, \mathrm{CH}_{3}\right), 0.94-0.85(\mathrm{~m}$, $\left.2 \mathrm{H}, \mathrm{CH}_{2}, \mathrm{CH}\right), 0.24$ (dd, $J=5.6,5.1 \mathrm{~Hz}, 1 \mathrm{H}, \mathrm{CH}_{2}$ ).

${ }^{13} \mathrm{C}$ NMR $\left(\mathrm{CDCl}_{3}, 100 \mathrm{MHz}\right): \delta=177.7(\mathrm{C}=\mathrm{O}), 42.9(\mathrm{C}), 31.2\left(\mathrm{CH}_{2} \mathrm{C}=\mathrm{O}\right)$, 24.6 $\left(\mathrm{CH}_{2} \mathrm{CH}_{2} \mathrm{C}=\mathrm{O}\right), 22.9(\mathrm{CH}), 22.7\left(\mathrm{CH}_{2} \mathrm{CH}_{3}\right), 17.2\left(\mathrm{CH}_{2}\right), 13.6\left(\mathrm{CH}_{3}\right)$.

HRMS (ESI+): $m / z\left[\mathrm{M}+\mathrm{Na}^{+}\right]$calcd for $\mathrm{C}_{8} \mathrm{H}_{13} \mathrm{NONa:} 162.0889$; found: 162.0896 .

\section{1-Methyl-4-azaspiro[2.4]heptan-5-one (6b)}

Obtained according to the general procedure using $n$ - $\mathrm{PrMgBr}$ (prepared from 1-bromopropane in $\mathrm{Et}_{2} \mathrm{O},[\mathrm{C}]=1.60 \mathrm{M}$ ). Purification by flash chromatography (100:0 to 90:10, EtOAc/iPrOH) afforded $\mathbf{6 b}$ as a mixture of diastereoisomers (92:8, $66 \mathrm{mg}, 53 \%)$.

Minor diastereoisomer isolated as a beige solid; $\mathrm{mp} 76-78^{\circ} \mathrm{C} ; R_{f}=$ 0.27 (100\%, EtOAc); $t_{R}=10.8,12.8 \mathrm{~min}(24 \%$ ee $)$.

IR (neat): 3170, 3056, 2928, 2872, 1685, 1460, 1361, 1285, 1024, 776 $\mathrm{cm}^{-1}$.

${ }^{1} \mathrm{H} \mathrm{NMR}\left(\mathrm{CDCl}_{3}, 400 \mathrm{MHz}\right): \delta=7.72(\mathrm{br} \mathrm{s}, 1 \mathrm{H}, \mathrm{NH}), 2.51-2.37(\mathrm{~m}, 2 \mathrm{H}$, $\mathrm{CH}_{2} \mathrm{C}=0$ ), 2.13 (ddd, $\mathrm{J}=12.7,9.4,8.1 \mathrm{~Hz}, 1 \mathrm{H}, \mathrm{CH}_{2} \mathrm{CH}_{2} \mathrm{C}=\mathrm{O}$ ), 1.98 (ddd, $\left.J=12.7,9.4,6.0 \mathrm{~Hz}, 1 \mathrm{H}, \mathrm{CH}_{2} \mathrm{CH}_{2} \mathrm{C}=0\right), 1.09\left(\mathrm{~d}, J=6.2 \mathrm{~Hz}, 3 \mathrm{H}, \mathrm{CH}_{3}\right)$, $0.86-0.78(\mathrm{~m}, 1 \mathrm{H}, \mathrm{CH}), 0.74\left(\mathrm{dd}, J=9.3,5.9 \mathrm{~Hz}, 1 \mathrm{H}, \mathrm{CH}_{2}\right), 0.38(\mathrm{dd}, J=$ $\left.5.9,6.0 \mathrm{~Hz}, 1 \mathrm{H}, \mathrm{CH}_{2}\right)$.

${ }^{13} \mathrm{C} \mathrm{NMR}\left(\mathrm{CDCl}_{3}, 100 \mathrm{MHz}\right): \delta=179.0(\mathrm{C}=\mathrm{O}), 43.5(\mathrm{C}), 31.3\left(\mathrm{CH}_{2} \mathrm{C}=0\right)$, $30.3\left(\mathrm{CH}_{2} \mathrm{CH}_{2} \mathrm{C}=\mathrm{O}\right), 17.5(\mathrm{CH}), 17.0\left(\mathrm{CH}_{2}\right), 13.8\left(\mathrm{CH}_{3}\right)$.

HRMS (ESI+): $m / z\left[\mathrm{M}+\mathrm{Na}^{+}\right]$calcd for $\mathrm{C}_{7} \mathrm{H}_{11} \mathrm{NONa:} 148.0733$; found: 148.0732 .

Major diastereoisomer isolated as a colorless oil; $R_{f}=0.21$ (100\%, EtO$\mathrm{Ac}) ; t_{R}=14.0,17.3 \mathrm{~min}(31 \% \mathrm{ee})$.

IR (neat): 3211, 2954, 2872, 1687, 1456, 1352, 1244, $732 \mathrm{~cm}^{-1}$.

${ }^{1} \mathrm{H} \mathrm{NMR}\left(\mathrm{CDCl}_{3}, 400 \mathrm{MHz}\right): \delta=7.44(\mathrm{br} \mathrm{s}, 1 \mathrm{H}, \mathrm{NH}), 2.53-2.35(\mathrm{~m}, 4 \mathrm{H}$, $\mathrm{CH}_{2} \mathrm{C}=\mathrm{O}$ ), 2.18 (ddd, $J=12.9,9.9,7.7 \mathrm{~Hz}, 1 \mathrm{H}, \mathrm{CH}_{2} \mathrm{CH}_{2} \mathrm{C}=\mathrm{O}$ ), 1.84 (ddd, $\left.J=12.9,9.9,5.4 \mathrm{~Hz}, 1 \mathrm{H}, \mathrm{CH}_{2} \mathrm{CH}_{2} \mathrm{C}=0\right), 1.03-0.97\left(\mathrm{~m}, 4 \mathrm{H}, \mathrm{CH}_{3}, \mathrm{CH}\right)$, 0.92-0.87 (m, $\left.1 \mathrm{H}, \mathrm{CH}_{2}\right), 0.21-0.17\left(\mathrm{~m}, 1 \mathrm{H}, \mathrm{CH}_{2}\right)$.
${ }^{13} \mathrm{C}$ NMR $\left(\mathrm{CDCl}_{3}, 100 \mathrm{MHz}\right): \delta=177.9(\mathrm{C}=\mathrm{O}), 42.9(\mathrm{C}), 31.2\left(\mathrm{CH}_{2} \mathrm{C}=\mathrm{O}\right)$, $24.3\left(\mathrm{CH}_{2} \mathrm{CH}_{2} \mathrm{C}=\mathrm{O}\right), 18.3\left(\mathrm{CH}_{2}\right), 15.1(\mathrm{CH}), 14.0\left(\mathrm{CH}_{3}\right)$.

HRMS (ESI+): $m / z\left[\mathrm{M}+\mathrm{Na}^{+}\right]$calcd for $\mathrm{C}_{7} \mathrm{H}_{11} \mathrm{NONa}$ : 148.0733; found: 148.0732 .

\section{1-Isopropyl-4-azaspiro[2.4]heptan-5-one (6c)}

Obtained according to the general procedure using isoamyl magnesium bromide (prepared from isoamyl bromide in $\mathrm{Et}_{2} \mathrm{O},[\mathrm{C}]=0.92 \mathrm{M}$ ). Purification by flash chromatography (100:0 to 90:10, EtOAc/iPrOH) afforded $\mathbf{6 c}$ as a mixture of diastereoisomers from which only the major diastereoisomer was isolated (78:22, $55 \mathrm{mg}, 36 \%)$.

Minor diastereoisomer; $t_{R}=7.8,9.0 \mathrm{~min}(38 \% e e)$.

Major diastereoisomer isolated as an orange oil; $R_{f}=0.35(100 \%$, EtOAc); $t_{R}=10.9,13.6 \mathrm{~min}(16 \%$ ee $)$.

IR (neat): 3205, 2956, 2870, 1687, 1462, 1365, 1240, $732 \mathrm{~cm}^{-1}$.

${ }^{1} \mathrm{H} \mathrm{NMR}\left(\mathrm{CDCl}_{3}, 400 \mathrm{MHz}\right): \delta=7.62(\mathrm{br} \mathrm{s}, 1 \mathrm{H}, \mathrm{NH}), 2.51-2.35(\mathrm{~m}, 2 \mathrm{H}$, $\mathrm{CH}_{2} \mathrm{C}=0$ ), 2.16 (ddd, $J=12.9,9.6,7.1 \mathrm{~Hz}, 1 \mathrm{H}, \mathrm{CH}_{2} \mathrm{CH}_{2} \mathrm{C}=0$ ), 1.91 (ddd, $\left.J=12.9,9.6,6.2 \mathrm{~Hz}, 1 \mathrm{H}, \mathrm{CH}_{2} \mathrm{CH}_{2} \mathrm{C}=0\right), 0.99-0.90\left(\mathrm{~m}, 7 \mathrm{H}, \mathrm{CH}_{3}\right.$, $\left.\mathrm{CH}\left(\mathrm{CH}_{3}\right)_{2}\right), 0.86\left(\mathrm{dd}, J=9.9,5.9 \mathrm{~Hz}, 1 \mathrm{H}, \mathrm{CH}_{2}\right), 0.76-0.69(\mathrm{~m}, 1 \mathrm{H}, \mathrm{CH})$, 0.23 (dd, $J=6.4,5.9 \mathrm{~Hz}, 1 \mathrm{H}, \mathrm{CH}_{2}$ ).

${ }^{13} \mathrm{C} \mathrm{NMR}\left(\mathrm{CDCl}_{3}, 100 \mathrm{MHz}\right): \delta=177.9(\mathrm{C}=\mathrm{O}), 43.3(\mathrm{C}), 31.5\left(\mathrm{CH}_{2} \mathrm{C}=\mathrm{O}\right)$, $29.6\left(\mathrm{CH}\left(\mathrm{CH}_{3}\right)_{2}\right), 29.3(\mathrm{CH}), 24.7\left(\mathrm{CH}_{2} \mathrm{CH}_{2} \mathrm{C}=\mathrm{O}\right), 22.6\left(\mathrm{CH}_{3}\right), 21.8\left(\mathrm{CH}_{3}\right)$, $16.7\left(\mathrm{CH}_{2}\right)$.

HRMS (ESI+): $m / z\left[\mathrm{M}+\mathrm{Na}^{+}\right]$calcd for $\mathrm{C}_{9} \mathrm{H}_{15} \mathrm{NONa}$ : 176.1046; found: 176.1051.

\section{1-Phenyl-4-azaspiro[2.4]heptan-5-one (6d)}

Obtained according to the general procedure using phenethyl magnesium bromide (prepared from phenethyl bromide in $\mathrm{Et}_{2} \mathrm{O},[\mathrm{C}]=1.00$ M). Purification by flash chromatography (100:0 to 90:10, EtOAc/iP$\mathrm{rOH}$ ) provided $\mathbf{6 d}$ as a mixture of diastereoisomers from which only the major diastereoisomer was isolated (97:3, $99 \mathrm{mg}, 53 \%$ ).

Major diastereoisomer isolated as a white solid; $\mathrm{mp} 100-102{ }^{\circ} \mathrm{C} ; R_{f}=$ 0.30 (100\%, EtOAc); $t_{R}=20.2,27.9 \min (32 \% e e)$.

IR (neat): 3200, 3084, 2929, 1687, 1605, 1499, 1451, 1352, 1251, $1203,910,730 \mathrm{~cm}^{-1}$.

${ }^{1} \mathrm{H} \mathrm{NMR}\left(\mathrm{CDCl}_{3}, 400 \mathrm{MHz}\right): \delta=8.12(\mathrm{br} \mathrm{s}, 1 \mathrm{H}, \mathrm{NH}), 7.31-7.26(\mathrm{~m}, 2 \mathrm{H}$ $\left.\mathrm{H}_{\mathrm{Ar}}\right), 7.21-7.17\left(\mathrm{~m}, 1 \mathrm{H}, \mathrm{H}_{\mathrm{Ar}}\right), 7.09-7.06\left(\mathrm{~m}, 2 \mathrm{H}, \mathrm{H}_{\mathrm{Ar}}\right), 2.50-2.32(\mathrm{~m}$, $3 \mathrm{H}, \mathrm{CH}_{2} \mathrm{C}=\mathrm{O}, \mathrm{CH}$ ), 1.89 (ddd, $J=13.2,9.9,6.8 \mathrm{~Hz}, 1 \mathrm{H}, \mathrm{CH}_{2} \mathrm{CH}_{2} \mathrm{C}=\mathrm{O}$ ), 1.80 (ddd, $J=13.2,9.9,6.3 \mathrm{~Hz}, 1 \mathrm{H}, \mathrm{CH}_{2} \mathrm{CH}_{2} \mathrm{C}=0$ ), 1.42 (dd, $J=10.0$, $6.7 \mathrm{~Hz}, 1 \mathrm{H}, \mathrm{CH}_{2}$ ), 1.18 (dd, $J=6.7,6.8 \mathrm{~Hz}, 1 \mathrm{H}, \mathrm{CH}_{2}$ ).

${ }^{13} \mathrm{C}$ NMR $\left(\mathrm{CDCl}_{3}, 100 \mathrm{MHz}\right): \delta=178.3(\mathrm{C}=\mathrm{O}), 137.6\left(\mathrm{C}_{\mathrm{Ar}}\right), 128.4(2$ $\left.\mathrm{CH}_{\mathrm{Ar}}\right), 127.8\left(2 \mathrm{CH}_{\mathrm{Ar}}\right), 126.2\left(\mathrm{CH}_{\mathrm{Ar}}\right), 45.5(\mathrm{C}), 31.1\left(\mathrm{CH}_{2} \mathrm{C}=0\right), 27.2(\mathrm{CH})$, $24.3\left(\mathrm{CH}_{2} \mathrm{CH}_{2} \mathrm{C}=\mathrm{O}\right), 16.1\left(\mathrm{CH}_{2}\right)$.

HRMS (ESI+): $m / z\left[\mathrm{M}+\mathrm{Na}^{+}\right]$calcd for $\mathrm{C}_{12} \mathrm{H}_{13} \mathrm{NONa}$ : 210.0889; found: 210.0885 .

\section{1-Benzyl-4-azaspiro[2.4]heptan-5-one (6e $)^{21}$}

Obtained according to the general procedure using 3-phenylpropylmagnesium bromide (prepared from 3-phenyl-1-bromopropane in $\left.\mathrm{Et}_{2} \mathrm{O},[\mathrm{C}]=0.88 \mathrm{M}\right)$. Purification by flash chromatography $(100: 0$ to 90:10, EtOAc/iPrOH) gave $\mathbf{6 e}$ as a mixture of diastereoisomers from which only the major diastereoisomer was isolated $(91: 9,161 \mathrm{mg}$, $80 \%$ )

Minor diastereoisomer; $t_{R}=19.3,21.7 \mathrm{~min}(47 \% e e)$.

Major diastereoisomer isolated as a yellow oil; $R_{f}=0.26(100 \%$, EtOAc); $t_{R}=27.5,44.0 \mathrm{~min}(21 \% e e)$. 
IR (neat): 3194, 3062, 2922, 1687, 1454, 1357, 1248, 730, $698 \mathrm{~cm}^{-1}$. ${ }^{1} \mathrm{H} \mathrm{NMR}\left(\mathrm{CDCl}_{3}, 400 \mathrm{MHz}\right): \delta=7.73($ br s, $1 \mathrm{H}, \mathrm{NH}), 7.30-7.25(\mathrm{~m}, 2 \mathrm{H}$, $\left.\mathrm{H}_{\mathrm{Ar}}\right), 7.22-7.17\left(\mathrm{~m}, 3 \mathrm{H}, \mathrm{H}_{\mathrm{Ar}}\right), 2.67-2.56\left(\mathrm{~m}, 2 \mathrm{H}, \mathrm{CH}_{2} \mathrm{Ph}\right.$ ), 2.49 (ddd, $J=$ 17.0, 9.9, 7.1 Hz, $1 \mathrm{H}, \mathrm{CH}_{2} \mathrm{C}=0$ ), 2.38 (ddd, $J=17.0,9.9,5.7 \mathrm{~Hz}, 1 \mathrm{H}$, $\mathrm{CH}_{2} \mathrm{C}=\mathrm{O}$ ), 2.22 (ddd, $J=12.9,9.9,7.1 \mathrm{~Hz}, 1 \mathrm{H}, \mathrm{CH}_{2} \mathrm{CH}_{2} \mathrm{C}=0$ ), 1.98 (ddd, $\left.J=12.9,9.9,5.7 \mathrm{~Hz}, 1 \mathrm{H}, \mathrm{CH}_{2} \mathrm{CH}_{2} \mathrm{C}=0\right), 1.37-1.33(\mathrm{~m}, 1 \mathrm{H}, \mathrm{CH}), 1.06$ (dd, $J=9.8,6.0 \mathrm{~Hz}, 1 \mathrm{H}, \mathrm{CH}_{2}$ ), 0.46 (dd, $J=6.4,6.0 \mathrm{~Hz}, 1 \mathrm{H}, \mathrm{CH}_{2}$ ).

${ }^{13} \mathrm{C} \mathrm{NMR}\left(\mathrm{CDCl}_{3}, 100 \mathrm{MHz}\right): \delta=178.0(\mathrm{C}=0), 140.7\left(\mathrm{C}_{\mathrm{Ar}}\right), 128.5(2$ $\left.\mathrm{CH}_{\mathrm{Ar}}\right), 128.0\left(2 \mathrm{CH}_{\mathrm{Ar}}\right), 126.2\left(\mathrm{CH}_{\mathrm{Ar}}\right), 43.3(\mathrm{C}), 35.2\left(\mathrm{CH}_{2} \mathrm{Ph}\right), 31.3$ $\left(\mathrm{CH}_{2} \mathrm{C}=\mathrm{O}\right), 24.8\left(\mathrm{CH}_{2} \mathrm{CH}_{2} \mathrm{C}=\mathrm{O}\right), 21.4(\mathrm{CH}), 17.6\left(\mathrm{CH}_{2}\right)$.

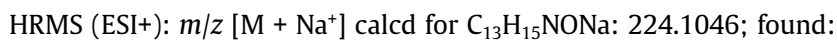
224.1043.

\section{1-Allyl-4-azaspiro[2.4]heptan-5-one (6f)}

Obtained according to the general procedure using pent-4-enylmagnesium bromide (prepared from 1-bromopent-4-ene in $\mathrm{Et}_{2} \mathrm{O},[\mathrm{C}]=$ $1.24 \mathrm{M})$. Purification by flash chromatography (100:0 to $90: 10$, $\mathrm{EtOAc} / \mathrm{iPrOH})$ provided $\mathbf{6} \mathbf{f}$ as a mixture of diastereoisomers from which only the major diastereoisomer was isolated (90:10, $109 \mathrm{mg}$, $72 \%)$.

Major diastereoisomer isolated as a yellow oil; $R_{f}=0.35(100 \%$, EtOAc); $t_{R}=13.6,16.9 \mathrm{~min}(31 \% e e)$.

IR (neat): 3207, 3080, 2920, 2851, 1687, 1460, 1357, 1251, 998, 912 $\mathrm{cm}^{-1}$.

${ }^{1} \mathrm{H} \mathrm{NMR}\left(\mathrm{CDCl}_{3}, 400 \mathrm{MHz}\right): \delta=7.57$ (br s, $\left.1 \mathrm{H}, \mathrm{NH}\right), 5.84$ (ddt, $J=17.4$, $10.4,5.9 \mathrm{~Hz}, 1 \mathrm{H}, \mathrm{CH}=\mathrm{CH}_{2}$ ), 5.05 (dd, $J=17.4,1.8 \mathrm{~Hz}, 1 \mathrm{H}, \mathrm{CH}_{2}=\mathrm{CH}$ ), 4.98 (dd, $J=10.4,1.8 \mathrm{~Hz}, 1 \mathrm{H}, \mathrm{CH}_{2}=\mathrm{CH}$ ), 2.52-2.35 (m, $2 \mathrm{H}, \mathrm{CH}_{2} \mathrm{C}=0$ ), 2.16 (ddd, $\left.J=12.8,9.7,7.2 \mathrm{~Hz}, 1 \mathrm{H}, \mathrm{CH}_{2} \mathrm{CH}_{2} \mathrm{C}=0\right), 2.07-1.87(\mathrm{~m}, 3 \mathrm{H}$, $\mathrm{CH}_{2} \mathrm{CH}_{2} \mathrm{C}=\mathrm{O}, \mathrm{CH}_{2} \mathrm{CH}=\mathrm{CH}_{2}$ ), 1.07 (dddd, $J=9.8,7.7,6.9,6.2 \mathrm{~Hz}, 1 \mathrm{H}, \mathrm{CH}$ ), 0.96 (dd, $J=9.8,5.9 \mathrm{~Hz}, 1 \mathrm{H}, \mathrm{CH}_{2}$ ), 0.31 (dd, $J=6.2,5.9 \mathrm{~Hz}, 1 \mathrm{H}, \mathrm{CH}_{2}$ ).

${ }^{13} \mathrm{C}$ NMR $\left(\mathrm{CDCl}_{3}, 100 \mathrm{MHz}\right): \delta=177.9(\mathrm{C}=\mathrm{O}), 136.9\left(\mathrm{CH}^{2} \mathrm{CH}_{2}\right), 115.0$ $\left(\mathrm{CH}_{2}=\mathrm{CH}\right), \quad 42.9$ (C), $33.3 \quad\left(\mathrm{CH}_{2} \mathrm{CH}=\mathrm{CH}_{2}\right), \quad 31.3 \quad\left(\mathrm{CH}_{2} \mathrm{C}=\mathrm{O}\right), \quad 24.5$ $\left(\mathrm{CH}_{2} \mathrm{CH}_{2} \mathrm{C}=\mathrm{O}\right), 19.8(\mathrm{CH}), 17.0\left(\mathrm{CH}_{2}\right)$.

HRMS (ESI+): $m / z\left[\mathrm{M}+\mathrm{Na}^{+}\right]$calcd for $\mathrm{C}_{9} \mathrm{H}_{13} \mathrm{NONa:} 174.0895$; found: 174.0903 .

\section{1-Vinyl-4-azaspiro[2.4]heptan-5-one (6g) ${ }^{49}$}

Obtained according to the general procedure using but-3-enylmagnesium bromide (prepared from 1-bromobut-3-ene in $\mathrm{Et}_{2} \mathrm{O},[\mathrm{C}]=0.62 \mathrm{M}$ ). Purification by flash chromatography (100:0 to 90:10, EtOAc/iPrOH) afforded $6 \mathbf{g}$ as a mixture of diastereoisomers from which only the major diastereoisomer was isolated (13:87, $74 \mathrm{mg}, 54 \%)$.

Major diastereoisomer isolated as an orange oil; $R_{f}=0.29(100 \%$, EtOAc); $t_{R}=11.7,15.4 \mathrm{~min}(26 \% e e)$.

IR (neat): 3184, 3074, 1696, 1658, 1632, $1370 \mathrm{~cm}^{-1}$.

${ }^{1} \mathrm{H} \mathrm{NMR}\left(\mathrm{CDCl}_{3}, 400 \mathrm{MHz}\right): \delta=7.88$ (br s, $\left.1 \mathrm{H}, \mathrm{NH}\right), 5.51$ (ddd, $J=17.0$, $\left.10.2,8.8 \mathrm{~Hz}, 1 \mathrm{H}, \mathrm{CH}=\mathrm{CH}_{2}\right), 5.06\left(\mathrm{dd}, J=17.0,1.7 \mathrm{~Hz}, 1 \mathrm{H}, \mathrm{CH}_{2}=\mathrm{CH}\right.$ ), $4.99\left(\mathrm{dd}, J=10.2,1.7 \mathrm{~Hz}, 1 \mathrm{H}, \mathrm{CH}_{2}=\mathrm{CH}\right), 2.53-2.30\left(\mathrm{~m}, 2 \mathrm{H}, \mathrm{CH}_{2} \mathrm{C}=0\right.$ ), 2.21-2.10 (m, $1 \mathrm{H}, \mathrm{CH}_{2} \mathrm{CH}_{2} \mathrm{C}=\mathrm{O}$ ), 2.01 (ddd, $J=12.8,9.4,5.9 \mathrm{~Hz}, 1 \mathrm{H}$, $\mathrm{CH}_{2} \mathrm{CH}_{2} \mathrm{C}=0$ ), 1.56-1.51 (m, $\left.1 \mathrm{H}, \mathrm{CH}\right), 0.95(\mathrm{dd}, J=9.2,6.4 \mathrm{~Hz}, 1 \mathrm{H}$, $\mathrm{CH}_{2}$ ), 0.87 (dd, $J=6.4,6.3 \mathrm{~Hz}, 1 \mathrm{H}, \mathrm{CH}_{2}$ ).

${ }^{13} \mathrm{C}$ NMR $\left(\mathrm{CDCl}_{3}, 100 \mathrm{MHz}\right): \delta=178.6(\mathrm{C}=\mathrm{O}), 135.8\left(\mathrm{CH}=\mathrm{CH}_{2}\right), 115.0$ $\left(\mathrm{CH}_{2}=\mathrm{CH}\right), 44.9(\mathrm{C}), 30.9\left(\mathrm{CH}_{2} \mathrm{C}=\mathrm{O}\right), 29.8\left(\mathrm{CH}_{2} \mathrm{CH}_{2} \mathrm{C}=\mathrm{O}\right), 27.2(\mathrm{CH}), 17.3$ $\left(\mathrm{CH}_{2}\right)$.

HRMS (ESI+): $m / z\left[\mathrm{M}+\mathrm{Na}^{+}\right]$calcd for $\mathrm{C}_{8} \mathrm{H}_{11} \mathrm{NONa:} 160.0738$; found: 160.0737 .
((4R,5R)-2,2-Dimethyl-1,3-dioxolane-4,5-diyl)bis(bis(2-methoxyphenyl)methanol) (15)

To a solution of diethyl 2,2-dimethyl-1,3-dioxolane-4,5-dicarboxylate $^{42}(2.42 \mathrm{mg}, 11.08 \mathrm{~mol})$ in THF $(11 \mathrm{~mL})$ was added 2-methoxyphenyl magnesium bromide $(67 \mathrm{mmol})$ dropwise at $0{ }^{\circ} \mathrm{C}$. The resulting mixture was stirred overnight at r.t. then $3 \mathrm{M}$ aq. $\mathrm{HCl}$ solution was added dropwise at $0{ }^{\circ} \mathrm{C}$. EtOAc was added, the layers were separated and the aqueous phase was extracted with EtOAc $(2 \times 20 \mathrm{~mL})$. The combined organic layers were washed with brine, dried over $\mathrm{MgSO}_{4}$, filtered and the solvents were removed in vacuo. Purification by flash chromatography (80:20, cyclohexane/EtOAc) afforded 15 (3.04 g, 47\%) as a yellow foam; $\mathrm{mp} 212-214{ }^{\circ} \mathrm{C} ; R_{f}=0.32$ (80:20, cyclohexane/EtOAc); $[\alpha]_{D}^{25}=+113.6\left(c 1.03, \mathrm{CHCl}_{3}\right)$.

IR (neat): 3507, 2978, 2935, 2834, 1601, 1583, 1486, 1235, 1089, 1030 $\mathrm{cm}^{-1}$.

${ }^{1} \mathrm{H}$ NMR $\left(\mathrm{CDCl}_{3}, 400 \mathrm{MHz}\right): \delta=7.95(\mathrm{dd}, J=7.9,1.7 \mathrm{~Hz}, 2 \mathrm{H}), 7.71(\mathrm{dd}$, $J=7.5,2.1 \mathrm{~Hz}, 2 \mathrm{H}), 7.08$ (ddd, $J=8.2,7.3,1.7 \mathrm{~Hz}, 2 \mathrm{H}), 6.93$ (ddd, $J=$ 8.0, 7.3, $1.4 \mathrm{~Hz}, 2 \mathrm{H}$ ), 6.79 (td, $J=7.5,2.1 \mathrm{~Hz}, 2 \mathrm{H}$ ), 6.75 (td, $J=7.5$, $1.7 \mathrm{~Hz}, 2 \mathrm{H}), 6.67(\mathrm{dd}, J=8.2,1.2 \mathrm{~Hz}, 2 \mathrm{H}), 5.91(\mathrm{dd}, J=7.9,1.4 \mathrm{~Hz}$, $2 \mathrm{H}$ ), 5.67 (s, $2 \mathrm{H}, \mathrm{OH}), 5.25$ (s, $2 \mathrm{H}, \mathrm{CH}), 3.36\left(\mathrm{~s}, 6 \mathrm{H}, \mathrm{CH}_{3} \mathrm{O}\right), 3.11(\mathrm{~s}$, $\left.6 \mathrm{H}, \mathrm{CH}_{3} \mathrm{O}\right), 1.59\left(\mathrm{~s}, 6 \mathrm{H}, \mathrm{CH}_{3} \mathrm{C}\right)$.

${ }^{13} \mathrm{C} \mathrm{NMR}\left(\mathrm{CDCl}_{3}, 100 \mathrm{MHz}\right): \delta=157.1\left(2 \mathrm{C}_{\mathrm{Ar}}\right), 154.9\left(2 \mathrm{C}_{\mathrm{Ar}}\right), 132.7(2$ $\left.\mathrm{C}_{\mathrm{Ar}}\right), 132.5\left(2 \mathrm{CH}_{\mathrm{Ar}}\right), 131.5\left(2 \mathrm{C}_{\mathrm{Ar}}\right), 128.0\left(2 \mathrm{CH}_{\mathrm{Ar}}\right), 127.1\left(2 \mathrm{CH}_{\mathrm{Ar}}\right), 126.8$

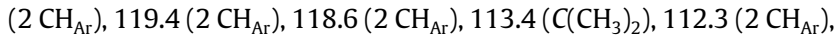
$110.5\left(\mathrm{CH}_{\mathrm{Ar}}\right), 80.2(2 \mathrm{COH}), 79.3(2 \mathrm{CH}), 56.0\left(2 \mathrm{CH}_{3} \mathrm{O}\right), 53.5\left(2 \mathrm{CH}_{3} \mathrm{O}\right)$, $28.3\left(2 \mathrm{CH}_{3}\right)$.

HRMS (ESI+): $m / z\left[\mathrm{M}+\mathrm{Na}^{+}\right]$calcd for $\mathrm{C}_{35} \mathrm{H}_{38} \mathrm{O}_{8} \mathrm{Na}$ : 609.2459; found: 609.2462 .

\section{Funding Information}

J.C. and P.S. gratefully thank the 'Ministère de l'enseignement supérieur et de la recherche', the 'Centre National de la Recherche Scientifique' and the 'Région Pays-de-la-Loire' for PhD fellowships.

\section{Acknowledgment}

The authors thank A. Durand, P. Gangnery, F. Legros, C. Jacquemmoz and E. Mebold for technical assistance and analyses.

\section{Supporting Information}

Supporting information for this article is available online at https://doi.org/10.1055/s-0036-1591933.

\section{References}

(1) (a) Salaün, J. Top. Curr. Chem. 2000, 207, 1. (b) Miyamura, S.; Itami, K.; Yamagushi, J. Synthesis 2017, 49, 1131.

(2) http://www.who.int/medicines/publications/essentialmedicines/en/

(3) Sinha, U.; Hollenbach, S. J.; Andre, P. U. S. Pat. Appl. US 20080254036 A1 20081016, 2008.

(4) Johansen, L. M.; Owens, C. M.; Mawhinney, C.; Chappell, T. W.; Brown, A. T.; Frank, M. G.; Altmeyer, R. PCT Int. Appl. WO 2008033466 A2 20080320, 2008.

(5) McCauley, J. A.; McIntyre, C. J.; Rudd, M. T.; Nguyen, K. T.; Romano, J. J.; Butcher, J. W.; Gilbert, K. F.; Bush, K. J.; Holloway, M. K.; Swestock, J.; Wan, B.-L.; Carroll, S. S.; DiMuzio, J. M.; 
Graham, D. J.; Ludmerer, S. W.; Mao, S.-S.; Stahlhut, M. W.; Fandozzi, C. M.; Trainor, N.; Olsen, D. B.; Vacca, J. P.; Liverton, N. J.J. Med. Chem. 2010, 53, 2443.

(6) (a) Ebner, C.; Carreira, E. M. Chem. Rev. 2017, 117, 11651. (b) Asymmetric Synthesis of Three-Membered Rings; Pelissier, H.; Lattanzi, A.; Dalpozzo, R., Eds.; Wiley: Weinheim, 2017. (c) Bartoli, G.; Bencivenni, G.; Dalpozzo, R. Synthesis 2014, 46, 979.

(7) For a recent example, see: Ji, Y.-Y.; Lin, S.-D.; Wang, Y.-J.; Su, M.B.; Zhang, W.; Gunosewoyo, H.; Yang, F.; Li, J.; Zhou, Y.-B.; Yu, L.F. Eur. J. Med. Chem. 2017, 141, 101.

(8) See for example: (a) Abu-Elfotoh, A.-M.; Phomkeona, K.; Shibatomi, K.; Iwasa, S. Angew. Chem. Int. Ed. 2010, 49, 8439. (b) Denton, J. R.; Davies, H. M. L. Org. Lett. 2009, 11, 787. (c) Song, Z.; Lu, T.; Hsung, R. P.; Al-Rashid, Z. F.; Ko, C.; Tang, Y. Angew. Chem. Int. Ed. 2007, 46, 4069.

(9) (a) Lindsay, V. N. G.; Lin, W.; Charette, A. B. J. Am. Chem. Soc. 2009, 131, 16383. (b) Lindsay, V. N. G.; Nicolas, C.; Charette, A. B. J. Am. Chem. Soc. 2011, 133, 8972. (c) Zhu, S.; Perman, J. A.; Zhang, X. P. Angew. Chem. Int. Ed. 2008, 47, 8460.

(10) Bégis, G.; Sheppard, T. D.; Cladingboel, D. E.; Motherwell, W. B.; Tocher, D. A. Synthesis 2005, 3186.

(11) Teng, H.-L.; Luo, Y.; Wang, B.; Zhang, L.; Nishiura, M.; Hou, Z. Angew. Chem. Int. Ed. 2016, 55, 15406.

(12) Kulinkovich, O. G.; Sviridov, S. V.; Vasilevskii, D. A. Synthesis 1991, 234.

(13) Reviews: (a) Kulinkovich, O. G.; de Meijere, A. Chem. Rev. 2000, 100, 2789. (b) Wolan, A.; Six, Y. Tetrahedron 2010, 66, 15. (c) Bertus, P.; Boeda, F.; Pearson-Long, M. S. M. Science of Synthesis Knowledge Updates 2012, 1, 1-50. (d) Bertus, P.; Szymoniak, J. Synlett 2007, 1346.

(14) Chaplinski, V.; de Meijere, A. Angew. Chem. Int. Ed. Engl. 1996, $35,413$.

(15) Bertus, P.; Szymoniak, J. Chem. Commun. 2001, 1792.

(16) Corey, E. J.; Rao, S. A.; Noe, M. S. J. Am. Chem. Soc. 1994, 116, 9345.

(17) No explanation was given to justify the variations of yields and ee for the preparation of $\mathbf{1}$.

(18) (a) Racouchot, S.; Sylvestre, I.; Ollivier, J.; Kozyrkov, Y. Y.; Pukin, A.; Kulinkovich, O. G.; Salaun, J. Eur. J. Org. Chem. 2002, 2160.

(19) (a) Konik, Y. A.; Kananovich, D. G.; Kulinkovich, O. G. Tetrahedron 2013, 69, 6673. (b) Kulinkovich, O. G.; Kananovich, D. G.; Lopp, M.; Snieckus, V. Adv. Synth. Catal. 2014, 356, 3615.

(20) de Meijere, A.; Chaplinski, V.; Winsel, H.; Kordes, M.; Strecker, B.; Gazizova, V.; Savchenko, A. I.; Boese, R.; Schill (née Brackmann), F. Chem. Eur. J. 2010, 16, 13862.

(21) Laroche, C.; Harakat, D.; Bertus, P.; Szymoniak, J. Org. Biomol. Chem. 2005, 3, 3482.

(22) The formation of the cyclopropane may also precede the formation of the five-membered ring, as proposed in ref 21.

(23) An alternative mechanism involving titanium ate complexes as proposed by Kulinkovich is also possible (and probable), but was not presented here to avoid overloading schemes. See: (a) Kulinkovich, O. G.; Kananovich, D. G. Eur. J. Org. Chem. 2007, 2121. (b) Kananovich, D. G.; Kulinkovich, O. G. Tetrahedron 2008, 64, 1536.
(24) The cis/trans relationship is defined from the two alkyl substituents on the cyclopropane.

(25) Seebach, D.; Beck, A. B.; Heckel, A. Angew. Chem. Int. Ed. 2001, $40,92$.

(26) Weber, B.; Seebach, D. Tetrahedron 1994, 50, 7473.

(27) Seebach, D.; Plattner, D. A.; Beck, A. K.; Wang, Y. M.; Hunziker, D.; Petter, W. Helv. Chim. Acta 1992, 75, 2171.

(28) The addition of Taddol to $\mathrm{Ti}(\mathrm{OiPr})_{4}$ in $\mathrm{CDCl}_{3}$ gives the spontaneous formation of $\mathrm{LTi}(\mathrm{OiPr})_{2}$ and $\mathrm{iPrOH}$, as shown by NMR spectroscopic analysis.

(29) Pescitelli, G.; Di Bari, L.; Salvadori, P. Organometallics 2004, 23, 4223.

(30) Unni, A. K.; Takenada, N.; Yamamoto, H.; Rawal, V. H. J. Am. Chem. Soc. 2005, 127, 1336.

(31) (a) Banphavichit, V.; Mansawat, W.; Bhanthumnavin, W.; Vilaivan, T. Tetrahedron 2004, 60, 10559. (b) Pettit, G. R.; Singh, S. B.; Herald, D. L.; Lloyd-Williams, P.; Kantoci, D.; Burkett, D. D.; Barkoczy, J.; Hogan, F.; Wardlaw, T. R. J. Org. Chem. 1994, 59, 6287. (c) Price, M. D.; Kurth, M. J.; Schore, N. E. J. Org. Chem. 2002, 67, 7769 .

(32) Wu, Y.-D.; Yu, Z.-X. J. Am. Chem. Soc. 2001, 123, 5777.

(33) Despite many attempts, the oxoesters derived from the direct hydrolysis of the intermediates B1 and $\mathbf{B 2}$ were never observed, even at low temperature.

(34) The nitrile $\mathbf{2 8}$ did not form cyclopropylamine to a large extent, and a Lewis acid is required to induce the cyclopropane formation, see ref 15 .

(35) The same kind of repulsion was proposed to explain the high diastereoselectivity observed in the carboxylic ester cyclopropanation, see ref $23 \mathrm{~b}$.

(36) For similar ring contractions, see: Williams, C. M.; Chaplinski, V.; Schreiner, P. R.; de Meijere, A. Tetrahedron Lett. 1998, 39, 7695.

(37) Love, B. E.; Jones, E. J. J. Org. Chem. 1999, 64, 3755.

(38) Beck, A. K.; Bastani, B.; Plattner, D. A.; Petter, W.; Seebach, D.; Braunschweiger, H.; Gysi, P.; La Vecchia, L. Chimia 1991, 45, 238.

(39) Cmrecki, V.; Eichenauer, N. C.; Frey, W.; Pietruszka, J. Tetrahedron 2010, 66, 6550.

(40) Seebach, D.; Dahinden, R.; Marti, R. E.; Beck, A. K.; Plattner, D. A.; Kuehnle, F. N. M. J. Org. Chem. 1995, 60, 1788.

(41) Du, H.; Zhao, D.; Ding, K. Chem. Eur. J. 2004, 10, 5964.

(42) Teller, H.; Flügge, S.; Goddard, R.; Fürstner, A. Angew. Chem. Int. Ed. 2010, 49, 1949.

(43) Hu, X.; Shan, Z.; Song, S. Tetrahedron: Asymmetry 2014, 25, 503.

(44) Dindaroglu, M.; Akyol, S.; Simsir, H.; Neudörfl, J. M.; Burke, A.; Schmalz, H. G. Tetrahedron: Asymmetry 2013, 24, 657.

(45) Wipf, P.; Jung, J.-K. J. Org. Chem. 2000, 65, 6319.

(46) Lai, G.; Guo, F.; Zheng, Y.; Fang, Y.; Song, H.; Xu, K.; Wang, S.; Zha, Z.; Wang, Z. Chem. Eur. J. 2011, 17, 1114.

(47) Shen, Y.; Feng, X.; Li, Y.; Zhang, G.; Jiang, Y. Eur. J. Org. Chem. 2004, 129.

(48) De Luca, L.; Giacomelli, G. Synlett 2004, 2180.

(49) Bertus, P.; Menant, C.; Tanguy, C.; Szymoniak, J. Org. Lett. 2008, 10, 777. 